\title{
The Inter-Relationship between Innovation Capability and SME Performance: The Moderating Role of the External Environment
}

\author{
Qinghua Fu ${ }^{1}$, Muhammad Safdar Sial ${ }^{2}$, Muhammad Zulqarnain Arshad ${ }^{3}{ }^{(0)}$, Ubaldo Comite ${ }^{4}$, \\ Phung Anh Thu ${ }^{5, * \mathbb{D}}$ and József Popp ${ }^{6}$
}

Citation: Fu, Q.; Sial, M.S.; Arshad, M.Z.; Comite, U.; Thu, P.A.; Popp, J. The Inter-Relationship between Innovation Capability and SME Performance: The Moderating Role of the External Environment. Sustainability 2021, 13, 9132. https:// doi.org/10.3390/su13169132

Academic Editor: Ashok Vaseashta

Received: 3 July 2021

Accepted: 13 August 2021

Published: 15 August 2021

Publisher's Note: MDPI stays neutral with regard to jurisdictional claims in published maps and institutional affiliations.

Copyright: (c) 2021 by the authors. Licensee MDPI, Basel, Switzerland. This article is an open access article distributed under the terms and conditions of the Creative Commons Attribution (CC BY) license (https:/ / creativecommons.org/licenses/by/ $4.0 /)$.
1 Economics and Management School, Wuhan University, Wuhan 430072, China; 2016101050084@whu.edu.cn 2 Department of Management Sciences, COMSATS University Islamabad (CUI), Islamabad 44000, Pakistan; safdarsial@comsats.edu.pk

3 Department of Management Sciences, Lahore Garrison University, Lahore 54000, Pakistan; muhammad.zulqarnain11@gmail.com

4 Department of Business Sciences, University Giustino Fortunato, 82100 Benevento, Italy; u.comite@unifortunato.eu

5 Faculty of Finance and Accounting, Nguyen Tat Thanh University, 300A Nguyen Tat Thanh Street, District 4, Ho Chi Minh City 70000, Vietnam

6 Institute of Economic Sciences, Hungarian University of Agriculture and Life Sciences, 2100 Gödöllő, Hungary; popp.jozsef@uni-mate.hu

* Correspondence: pathu@ntt.edu.vn

\begin{abstract}
Small and Medium-Sized Enterprises (SMEs) play a crucial part in a country's economic growth and sustainable development. The purpose of this study is to investigate the relationship between innovation and the performance of SMEs. An external environmental factor acts as a moderating variable between the exogenous and endogenous variables. Data were collected from 350 textile SMEs operating in Pakistan using a cross-sectional study design through self-administered questionnaires. Of these, only 335 surveys were valid for further analysis. The structural equational modeling technique was used for analyzing the data and testing the hypotheses that innovation and the external environment affect an SME's performance. The results indicate a significant association between innovation and SME performance, and the external environment has a moderating impact on innovation and SME performance. This paper offers valuable recommendations to senior managers and owners of SMEs to consider the innovation and external environment as crucial factors when assessing their SME's performance. This study contributes towards the body of knowledge on this subject and can help practitioners and researchers explore the effects of innovation and the external environment on the performance of SMEs.
\end{abstract}

Keywords: innovation; smart-PLS approach; external environment; SMEs' performance

\section{Introduction}

Due to the increasing trend of globalization, the ways of doing business have drastically changed. The market scenario is transforming whereby customers' needs and wants are changing, the rivalry between competitors is getting stronger, and new technological systems are being implemented. All these factors are causing the environment to become aggressive, which makes it hard to maintain its growth and competitive advantage. Nowadays, traditional business models are no longer competitive in the long term and need to innovate. Therefore, the firms who will survive in the market are those who will provide real value for their consumer through an innovative business model created on a sustainable basis [1]. More importantly, a necessity has been developed for the firms to improve innovation in order to sustain the business environment [2]. In other words, the business market is changing constantly due to several external factors [3]. The capability of organizations 
to be responsive to these changes can lead to success in the current business situation. To fulfill customer needs, firms have to develop innovative processes to improve products and services, which would lead to customer satisfaction and firm competitiveness. This activity requires innovation and is an integral part of the firm's sustained growth and success in a dynamic environment [3]. Innovation and sustainability form an important link in the pursuit of environmental, economic, and social development. Innovation has been seen as an important tool for achieving sustainability [4]. Plentiful attention has been given to the concept of innovation in different business fields [5]. For instance, different scholars recognize innovation as important to ensure improved firm performance, profitability, and long-term survival in the business market $[5,6]$. The firms that possess a high capacity to implement the innovation are considered to be risk-taking, proactive, supporting the notion of new ideas, and constructing new business strategies [7]. As a result, innovation is the root cause of increased business performance [8,9]. Hence, some scholars have confirmed in their studies that innovation is directly linked with performance and a competitive edge [10-12].

Owing to the increasing trend in global competition, organizations must adopt more sustainable practices that are aligned with prevailing environmental conditions [13]. Firm performance has a significant impact on the development and economic growth of countries. Firm performance is regarded as the business's accomplishment in the market. Nowadays, firm performance is one of the critical issues for all organizations across the world because they face rapid competition and globalization. Sustaining a SME's performance is significant and is still attracts the attention of many researchers; even today, it is still compelling due to the emerging global competition and sustainable growth in the context of developing countries [14]. However, following the dynamic characteristic of the business market, some researchers have examined the moderating role of the external environment among innovation and firm performance [15-17]. Moreover, researchers have attempted to discern how certain environmental factors impact innovation and performance. As the market continuously changes, the current products and services become outdated. Therefore, firms must strive to introduce new products based on the market demand to limit the threat from their competitors and product shortage. This would go a long way in strengthening the company's position. Innovation allows firms to act proactively and strive for new ways to attain the market demands [13].

The business environment in which companies are operating in now is highly diverse and uncertain. Therefore, SMEs are required to incorporate innovation to synchronize with the changing trend and move parallel with the market. To avail the opportunity in the new business, environment firms have to generate or improve their existing products. This indicates a strong commitment towards organizational success and enhances firm competitiveness. Another implication of innovation is that it makes SMEs knowledgebased enterprises and promotes the adoption of modern technologies that helps them to tackle external components. This goal can be achieved by the sharing of new innovative ideas in the organization. It should be flexible enough to mold its systems for the betterment of the firm and shape the company future's direction.

SMEs are regarded as the economic engine and pillar of economic development in every economy. In developing countries, the economic growth mostly depends on the performance of SMEs. Despite the significant economic support and contribution headed for development, SMEs' performance in developing countries remains below the expectation level [18]. In Pakistan, the situation is somewhat similar to other developing countries. Pakistani SMEs are striving for smooth economic growth and business sustainability. For business survival and growth, the SMEs in Pakistan have to develop the ability to introduce innovation. These SMEs are required to exploit the opportunity in the market on the basis of innovation to cope with the dynamic environment [19].

In the current literature, the impact of innovation on firm performance has been widely acknowledged $[20,21]$. However, there is no consensus on the nature of the relationship, i.e., a positive or negative impact of innovation on firm performance. For firms, innovation can be the source of cash flow. Furthermore, firms require massive investments for innovation 
activities and long periods of time to realize the profit from the innovation [22]. In the management discipline, different terminology is used for innovation, which explains the inconsistent relationship between innovation and firm performance [23-26].

Moreover, prior scholars have found that organizational innovation is highly critical not only for large corporations but also for SMEs [18]. Innovation has been classified as a crucial element for firms' wealth generation [27]. The role of innovation is considered quite instrumental in augmenting firms' performance [28]. Studies have shown that the external environment influences organizational performance [29]. Empirical evidence reveals that the external environment is, directly and indirectly, related to organizational performance [30,31]. It has been demonstrated that external environmental forces and innovation could be the destructive elements that may harm the SMEs' performance if firms do not plan and organize efficiently [32]. It is postulated that social, economic, and environmental constraints are not just analytical concepts but are the key aspects for the alignment of the business model and strategies of the firm [32]. Therefore, this study objectively focuses on how innovation influences an SME's performance and how the external environment moderates this relationship.

Based on the above discussion, this paper aims to analyze the relationship between the external environment, innovation, and firm performance. The model has been constructed to examine the moderation of the external environment. This study will contribute to the body of knowledge on this topic and provide clarification on the role of the external environment. Ultimately, the findings will demonstrate how innovation is important for firms to keep running their businesses in a highly intense market.

\section{Literature Review}

This section covers the historical and critical reviews from the literature on innovation, the external environment, and the performance of SMEs. Through this section, a significant critical review and the logic behind this study are revealed

\subsection{Firm Performance}

Performance has been a vital research topic among researchers for many years $[20,33]$. Some researchers consider organizational performance as value creation for stakeholders, while others view it as the achievement of a corporate goal [34]. The success of an organization is measured by performance indicators [35,36], which state that organizational performance is measured by how an organization uses its resources to forecast its future position. There are serval ways to measure organizational performance because it is a multi-dimensional construct [33]. Researchers have used different approaches for measuring performance, and diverse classifications have been given to various performance measures, depending on how they are arrived at [37].

Performance measurement is an issue that has not gained enough attention in SMEs. SMEs usually ignore a holistic approach to performance measurement. Small companies often have a greater focus on their financial and operational performance [38]. It is quite rare for SMEs to focus on research and development, innovation, and human resourcerelated measures of performance [35]. Unlike large companies, SMEs cannot afford to install expensive software platforms that meet their specific needs of measuring their financial and non-financial performance [35,39].

\subsection{Innovation}

As cited by Hansen and Wakonen [40], the first definition of innovation was coined by Schumpeter in the late 1920s. According to Schumpeter, innovation is considered to be novel goods or a novel quality of the goods, a new production process, a newer market, a novel source of supply, or a novel organizational structure. In this regard, doing things differently is considered an innovation. However, Hansen and Wakonen [40] argued that "it is practically impossible doing things identically". Therefore, every change qualifies as an innovation. 
According to the OECD (Organization for Economic Co-operation and Development, Paris, France), "innovation is the implementation of any new or significantly improved product (goods or services), operational processes (methods of production and service delivery), marketing methods (packaging, sales, and distribution methods), organizational/managerial methods, processes in business practices, workplace organization or external relations" [41]. To excel in highly competitive local and global markets, innovation is only practical [23].

The importance of innovation has been acknowledged by large firms already. However, today, the importance of innovation is also gaining attention in developing and developed countries, specifically in the context of SMEs [18]. Innovation is a crucial element of firm success in a highly competitive environment. Thus, the firms that innovate could boost their performance to a higher level compared to their rivals. Researchers have found that those firms with a high level of innovation activities and capabilities gain better responses from the environment and obtain a competitive advantage to enhance their performance $[2,16,20]$. Various scholars and researchers stressed that one of a firm's vital resources is innovation, as it has a significant effect on a firm's performance [4,42-44]. Robust findings show a significant and positive relationship between innovation and firm performance $[4,44-46]$. Hence, we can hypothesize that:

Hypothesis 1 (H1). Innovation has a significant relationship with SME performance.

\subsection{External Environment}

Any organization (profit or not-for-profit) cannot operate in a vacuum. All organizations are established and managed according to the environment. Any organization that interacts with the environment is considered to be an open system organization [47]. Thus, the environment has a significant influence on organizational performance and activities. Most business planning and decision-making activities are undertaken according to environmental changes [48]. A successful organization always keeps on reconfiguring its resources and strategies according to the environment.

Currently, organizational survival and success have become tough in the highly competitive market. Therefore, there must be a perfect match between internal organizational resources and external environment conditions [49]. Successful organizations must continuously scan the latest necessary information about their environment [48]. Firms can attain long-term competitiveness only when their resources, capabilities, and strategies are aligned with the external environmental factors [50]. The external environment denotes a process that varies the effect of the independent variables (IVs) on firm performance in the light of RBV. This variable is one of the exogenous variables with a moderating effect [18]. In addition, several researchers, such as Dess and Beard [51] and Jansen et al. [52], suggest that the external environment moderates the relationship between firms' resources and performance. Hence, we can hypothesize that:

Hypothesis 2 (H2). The external environment moderates the relationship between innovation and SME performance.

In the view of RBV, Wernerfelt [53] and Barney et al. [54] stress that a firm's competitive advantages depend on the uniqueness of the resources that the firm possesses. As the RBV emphasized, the growth and survival of small firms must identify their critical resources. A resource-based view of the firm represents the foundation for small firms to strategize based on critical sources that enable them to gain a competitive advantage [55]. However, little effort has been made to unveil those resources that are possessed and employed by small firms to achieve and sustain a competitive advantage [56]. It is commonly thought that small firms may be capable of surviving and performing with lesser resources when the environment is favorable and less competitive. However, in a hostile and hyper-competitive environment, firms must possess superior resources [56]. A review of the literature suggests that innovation has a significant effect on firm performance [15-17]. In general, innovation is the critical element for a firm's sustainable high performance in competitive environ- 
ments $[57,58]$. In addition, previous research has proven that the external environment has an influence on firms' performance [59]. Empirical evidence suggests that the external environment is, directly and indirectly, related to organizational performance. Specifically, studies have established the moderating effect of the external environment on organizational performance $[30,31]$. Thus, innovation and the external environment impact the performance of the SMEs. Therefore, the following framework is put forward in Figure 1.

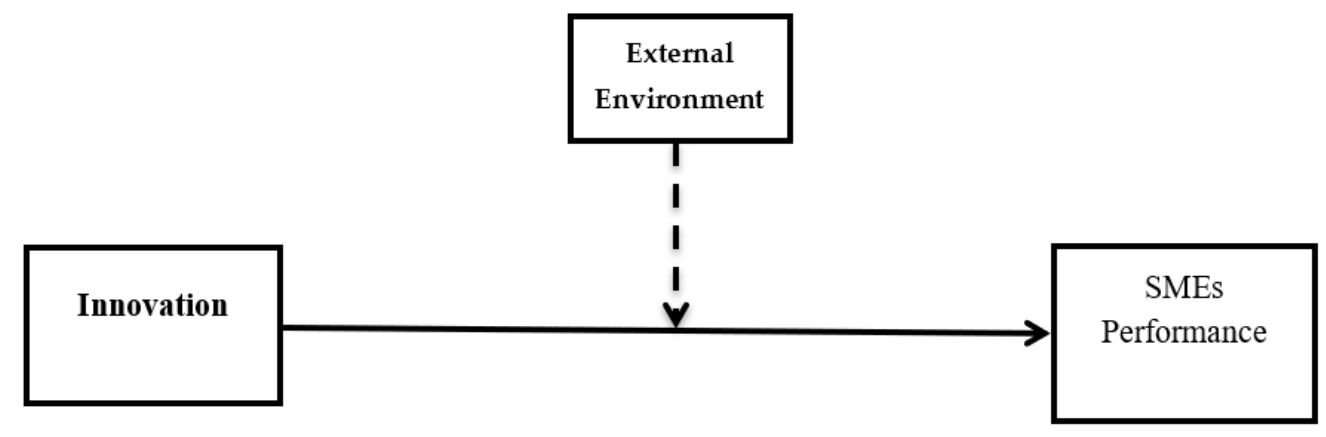

Figure 1. Proposed research model: This figure shows the path effects for H1 and H2. H1 shows how the independent variable " $X$ " affects the dependent variable " $Y$ ", and $H 2$ shows how moderating variable " $M$ " influences the direct relationship between " $X$ " and " $Y$ ", where innovation $(X)=$ the independent variable, the SMEs' performance $(Y)=$ the dependent variable, and the external environment $(\mathrm{M})=$ the moderating variable.

\section{Methods and Materials}

The data were collected from SMEs of Pakistan from October 2019 till March 2020, through a self-administered survey technique. In this research, a simple random sampling technique was used. The unit of analysis for the current study is an organizational level, which is why the primary respondents included owners, CEOs/managing directors, and senior managers, because they represent the organization, i.e., the SME. For the minimum sample size determination, we used the software named $G^{*}$ power for calculation. As in the current study model, there is a maximum of 2 predictors that influence the endogenous variable (performance). A small effect size (0.02) was set in the software along with a power of 0.95. A sample of 350 SMEs was required for an exact representation of the population based on the sample table provided by [60]. Hence, a total of 350 questionnaires was distributed from which 335 were returned and usable.

The questionnaire was prepared in dual languages, i.e., Urdu and English. Questionnaires based on two languages are known as bilingual questionnaires [61]. A bilingual questionnaire for this study was prepared with an authentically verified expert translator. The translation process was then followed by the standards recommended for academic research [62].

\subsection{Measures}

The theoretical constructs in the conceptual model are measured using multi-items and uni-item scales. A seven-point Likert scale was used for measuring the response ( 1 "Strongly Disagree" to 7 "Strongly Agree").

\subsubsection{Innovation}

The innovation scale is adopted from Weerawardena [63], which is measured by ten items: product innovation ( 2 items), managerial innovation ( 2 items), process innovation ( 2 items), and market innovation (4 items).

\subsubsection{External Environment}

The external environment scale is adopted from Jaworski and Kohli [64], which is composed of 15 items: market turbulence (5 items), technological turbulence (4 items), and competitive intensity (6 items). 


\subsubsection{Performance}

Measuring the firms' performance is adopted from Valmohammadi [65], which consists of 5 items. Respondents were asked to rate their performance concerning their competitors in the past three years.

\section{Results and Discussion}

In this research, the Partial Least Squares (PLS) analysis technique was used, using Smart-PLS 3.2.8 software [66]. The first phase of analysis was the assessment of the measurement model, in which the reliability and validity of the constructs were analyzed. Subsequently, we used the assessment of measurement model in which we tested the significance of the hypotheses.

\subsection{Assessment of Measurement Model}

According to Hair et al. [66], at first, we have to assess the construct's reliability and validity in the measurement model. In this research, the hierarchical component modelling technique was used because the constructs are higher-order and the model is ReflectiveReflective. For model assessment, the repetitive-indicator approach was utilized [67]. Cronbach's Alpha and the composite reliability were evaluated for indicator reliability, and convergent-validity and discriminant validity were assessed for construct validation. Results indicate that the composite reliability (CR) values of the external environment, innovation, and SME performance are $0.941,0.944$, and 0.935 , as stated below in Table 1 , and the value of Cronbach's Alpha is 0.877 (external environment), 0.823 (innovation), and 0.923 (SME performance), respectively.

Table 1. Reliability and validity.

\begin{tabular}{lllll}
\hline & Cronbach's Alpha & rho_A & CR & AVE \\
\hline EXT ENV & 0.877 & 0.934 & 0.941 & 0.716 \\
ETCI & 0.868 & 0.884 & 0.915 & 0.678 \\
ETMK & 0.723 & 0.866 & 0.902 & 0.619 \\
ETTB & 0.767 & 0.855 & 0.907 & 0.636 \\
SME FP & 0.923 & 0.934 & 0.935 & 0.733 \\
INO & 0.823 & 0.937 & 0.944 & 0.757 \\
INPD & 0.747 & 0.884 & 0.923 & 0.628 \\
INPR & 0.728 & 0.866 & 0.905 & 0.659 \\
INMG & 0.775 & 0.855 & 0.912 & 0.694 \\
INMK & 0.827 & 0.934 & 0.923 & 0.711 \\
\hline
\end{tabular}

Note: EXT ENV = External Environment; ETCI = Competitive Intensity; ETMK = Market Turbulence; ETTB = Technological Turbulence; INO = Innovation; INPD = Product Innovation; INPR = Process Innovation; INMG = Managerial Innovation; INMK = Market Innovation; SME FP = SME Performance.

The threshold value of AVE should be higher than 0.5. In the current assessment, the convergent validity values are 0.716 (external environment), 0.757 (innovation), and 0.733 (SME performance), as shown above in Table 1. According to [68], one of the indicators used to measure the model's discriminant validity is the Fornell-Larcker criterion. Table 2 indicates that the square root value of AVE (diagonal) is higher than the correlations (off-diagonal) for all reflective constructs. All the values show that there is no issue of multi-collinearity among the constructs.

Furthermore, to be aligned with the recent reporting of the PLS-SEM results [66], the new Heterotrait-Monotrait ratio (HTMT), introduced by [69], was also utilized. HTMT is the ratio of the "between-trait correlations" to the "within-trait correlations" [66]. The value used as a threshold for the HTMT criterion is 0.9 , which implies that two of the construct measures should not correlate above 0.9 to confirm its discriminant validity. All the respective values were confirmed to be below the threshold levels, as stated in Table 3 . 
Table 2. Fornell-Larcker Criterion.

\begin{tabular}{ccccccccc}
\hline & ETCI & ETMK & ETTB & INMG & INMK & INPD & INPR & SME FP \\
\hline ETCI & 0.793 & & & & & & & \\
ETMK & 0.678 & 0.806 & & & & & & \\
ETTB & 0.758 & 0.604 & 0.833 & & & & & \\
INMG & 0.287 & 0.297 & 0.364 & 0.838 & & & & \\
INMK & 0.547 & 0.446 & 0.541 & 0.727 & 0.824 & & & \\
INPD & 0.403 & 0.336 & 0.411 & 0.748 & 0.648 & 0.884 & & \\
INPR & 0.246 & 0.216 & 0.236 & 0.675 & 0.618 & 0.723 & 0.854 & \\
SME FP & 0.455 & 0.366 & 0.521 & 0.529 & 0.491 & 0.631 & 0.447 & 0.857
\end{tabular}

Note. $\quad$ EXT ENV = External Environment; ETCI = Competitive Intensity; ETMK = Market Turbulence ETTB $=$ Technological Turbulence; INO = Innovation; INPD = Product Innovation; INPR = Process Innovation; INMG = Managerial Innovation; INMK = Market Innovation; SME FP = SME Performance.

Table 3. Discriminant Validity (HTMT criterion).

\begin{tabular}{cccccccccc}
\hline & ETCI & ETMK & ETTB & INMG & INMK & INO & INPD & INPR & SME FP \\
\hline ETCI & 0.793 & & & & & & & & \\
ETMK & 0.678 & 0.806 & & & & & & & \\
ETTB & 0.758 & 0.604 & 0.833 & & & & & & \\
INMG & 0.287 & 0.297 & 0.364 & 0.838 & & & & & \\
INMK & 0.547 & 0.446 & 0.541 & 0.727 & 0.824 & & & & \\
INO & 0.462 & 0.397 & 0.476 & 0.880 & 0.809 & 0.746 & & & \\
INPD & 0.430 & 0.360 & 0.411 & 0.748 & 0.648 & 0.864 & 0.884 & & \\
INPR & 0.246 & 0.216 & 0.260 & 0.675 & 0.680 & 0.853 & 0.723 & 0.854 & \\
SME FP & 0.450 & 0.366 & 0.521 & 0.529 & 0.491 & 0.592 & 0.631 & 0.447 & 0.857 \\
\hline
\end{tabular}

Note. $\quad$ EXT ENV = External Environment; ETCI = Competitive Intensity; ETMK = Market Turbulence; ETTB $=$ Technological Turbulence; INO = Innovation; INPD = Product Innovation; INPR = Process Innovation; INMG = Managerial Innovation; INMK = Market Innovation; SME FP = SME Performance.

\subsection{Assessment of Structural Model}

Once the criteria of the measurement model assessment are filled, we have to assess the next model called the structural model. In the evaluation of the structural model, we evaluate the hypothesis testing (path-coefficient), effect size $\left(f^{2}\right)$, and coefficient of determination ( $\mathrm{R}^{2}$ value). In Smart-PLS, boot-strapping of 500 sample sizes was run with the level of significance of $5 \%$ and a two-tailed test. In hypothesis testing, we assessed the T-statistics and $p$-value for accepting or rejecting the hypothesis. According to Table 4 , the value of the effect size $\left(\mathrm{f}^{2}\right)$ of the two endogenous variables-innovation and the external environment-is 0.260 and 0.094 , which is a medium and small effect. The first hypothesis, i.e., H1, was accepted $(\beta=0.454, \mathrm{t}=8.321, p<0.01)$, as shown in Table 5 and Figure 2 . The value of the coefficient of determination $\left(R^{2}\right.$-value) of the model is $40.6 \%$, which is a medium effect. This shows that the endogenous variables, namely innovation and the external environment, explain $40 \%$ of the variance in the endogenous variable, namely SME performance.

Table 4. Effect size.

\begin{tabular}{ccc}
\hline Exogenous Construct & F2 & Effect Size \\
\hline Innovation & 0.260 & medium \\
Environmental Turbulence & 0.094 & small \\
\hline
\end{tabular}

Table 5. Direct hypothesis testing.

\begin{tabular}{ccccccc}
\hline & Hypo & Beta & Standard Error & T-Statistics & P-Statistics & Remarks \\
\hline H1 & INO- $>$ SME FP & 0.454 & 0.055 & 8.321 & $0.000 *$ & Supported \\
\hline Note: ${ }^{*}$ Level of significance $<0.001$. & & &
\end{tabular}




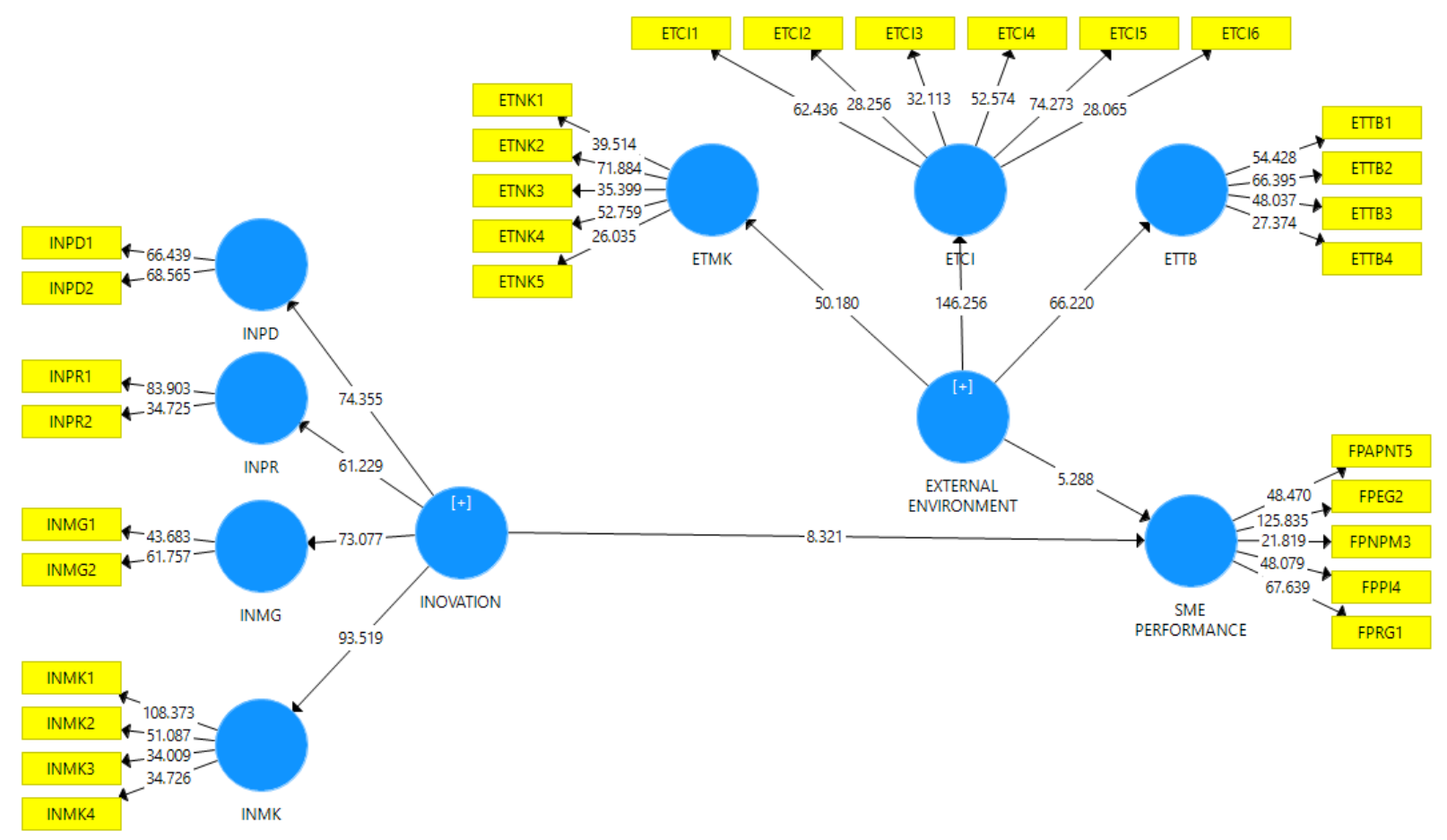

Figure 2. PLS Bootstrapping for the direct hypothesis testing.

\subsection{Testing Moderating Effect}

In this study, the external environment is tested as a moderator in the relationship between innovation and SME performance. When the direct effect of the independent variable on the dependent variable changes or is influenced by the presence of another variable, then that variable acts as an intervening variable (moderating variable) in the nexus [66]. For moderation testing, the same procedure of bootstrapping is used. Table 6 and Figure 3 show the positive nexus between innovation and SME performance ( $\beta=0.155$, $\mathrm{t}=3.785, p<0.01$ ).

\subsection{Analysis of Interaction Effect}

There are different methods and procedures used in the interaction analysis [70]. However, the most widely used approach is simple slope analysis. In this procedure, the slope and intercept are calculated for specific intervals of the moderator variable. Based on [68], an analysis of the moderation effect, the results signify that the external environment moderates the association between innovation and SME performance. Innovation limits the adverse effects of the external environment on firm performance. Due to innovation, firms benefit from the opportunities presented in the changing environment, which positively impacts their performance. Firms that operate in a highly dynamic environment tend to be more influenced by innovation. They applied innovation in their product and processes. These findings imply that the association among innovation and SME performance would be strengthened by the size of the interaction term. In other words, in a firm with a high external environment, innovation capability becomes more important in explaining SME performance. In addition, below in Figure 4, which represents the external environment-innovation interaction plot [71], the line tagged as the 'High External Environment' indicates that a high level of external environment awareness has a steeper gradient compared to a low external environment awareness. This result signifies that the positive nexus between innovation and SME performance gets stronger for a firm with a high external environment awareness. Indeed, innovation is recognized as an essential tool for firms to combat environmental issues that can impact their performance [72]. 
Table 6. Results of the moderating effect hypothesis testing.

\begin{tabular}{ccccccc}
\hline & Hypo & Beta & Standard Error & T-Statistics & P-Statistics & Remarks \\
\hline H2 & $\begin{array}{c}\text { Moderating of } \\
\text { INO*EXT ENO- > FP }\end{array}$ & 0.155 & 0.039 & 3.785 & $0.000 *$ & Supported \\
\hline
\end{tabular}

Note: ${ }^{*}$ Level of significance $<0.001$.

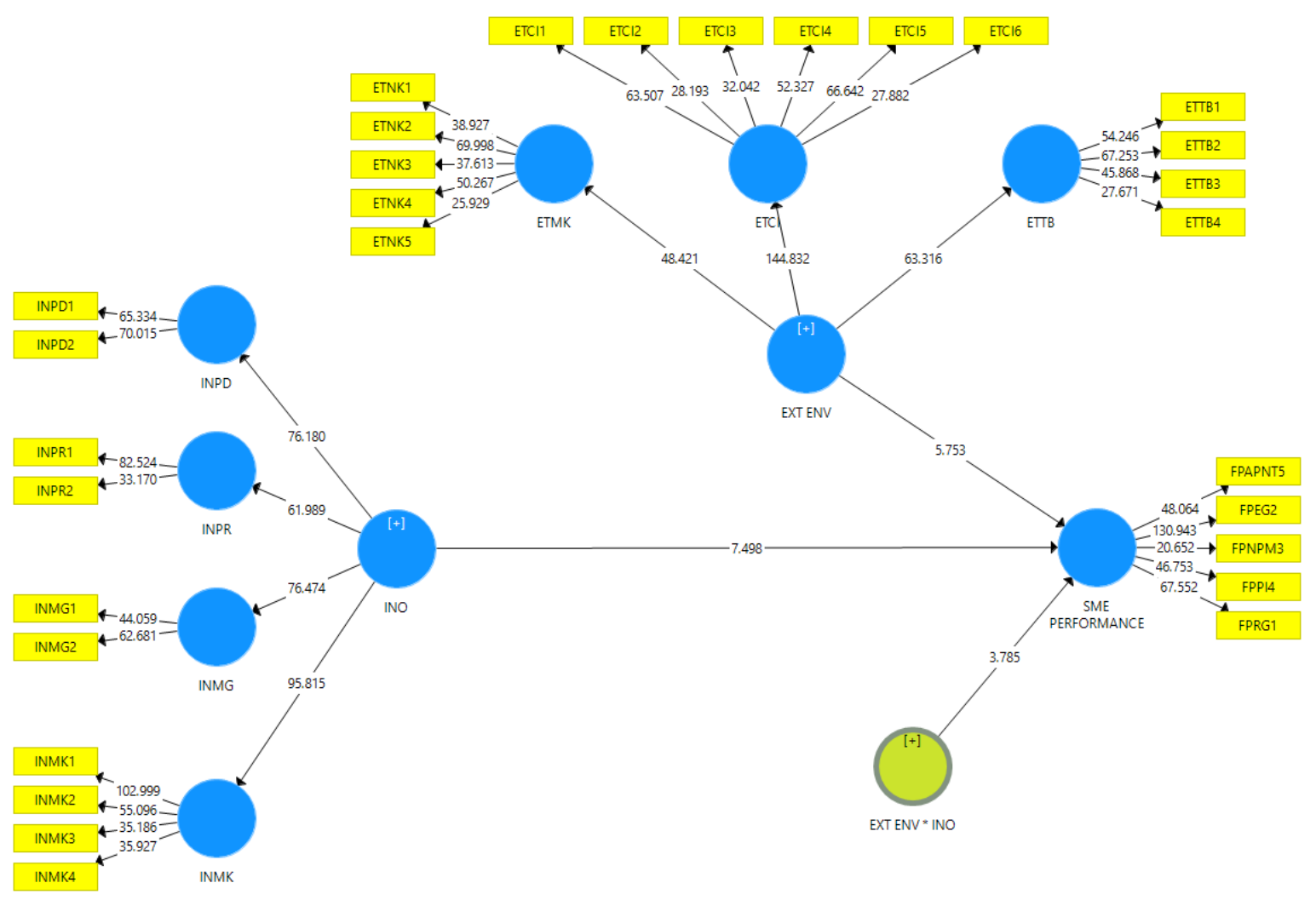

Figure 3. PLS Bootstrapping for the moderating hypothesis testing.

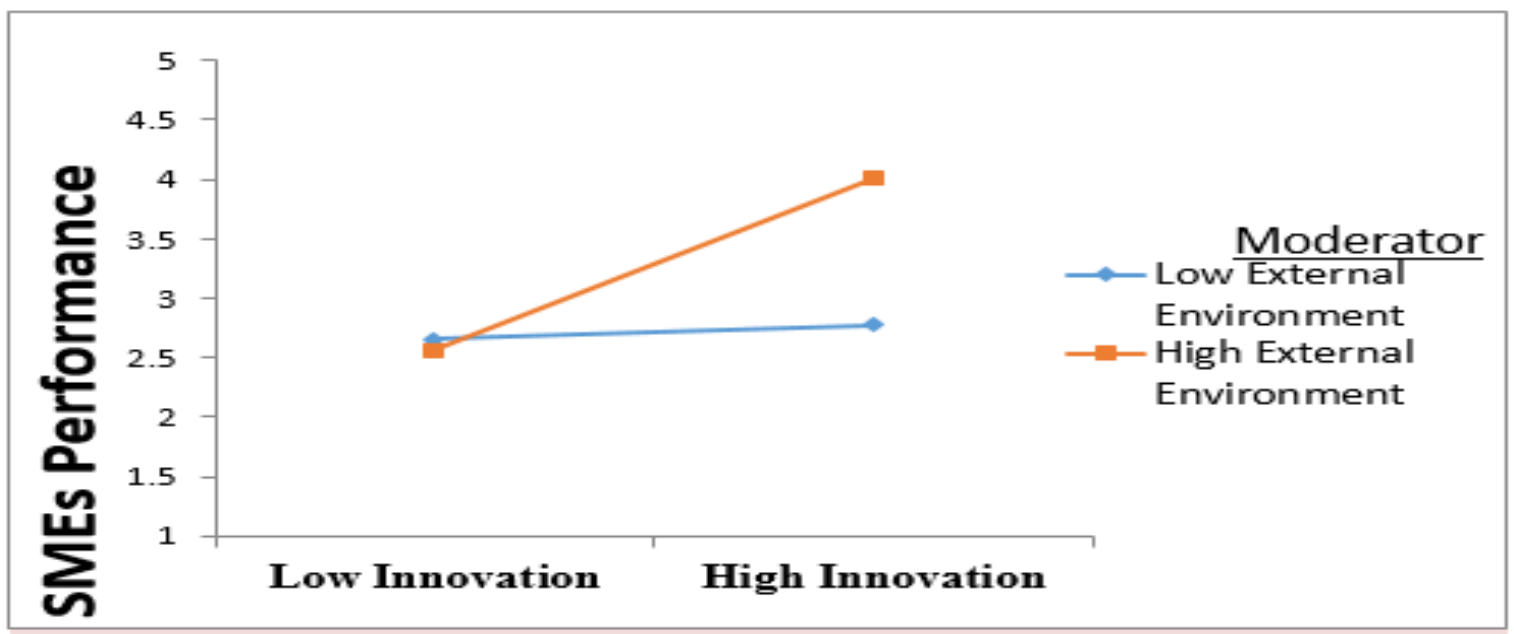

External Environment strengthens the positive relationship between Innovation and SMEs Performance.

Figure 4. The interaction effect. 


\section{Conclusions}

This study objectively tested the relationship between innovation, the external environment, and performance of Pakistani SMEs. To accomplish these objectives, we tested two main hypotheses. In the first hypothesis, $\mathrm{H}_{1}$, we examined the direct relationship between innovation and SME performance. In the second hypothesis, $\mathrm{H}_{2}$, we tested whether the external environment moderates the association between innovation and an SME's performance. Acceptance of $\mathrm{H}_{1}$ indicates that innovation is regarded as one of the crucial abilities of SMEs to help them to gain a competitive advantage. The results of our current study postulate that there is a significant positive correlation between innovation and performance. Current findings are consistent with previous research on this topic $[2,23,24,49]$. Therefore, the SMEs that want to gain competitiveness must focus on the innovation activities related to products, processes, services, and marketing [73]. Consequently, SMEs can gain a higher market share based on the uniqueness of their innovation strategy, which should aim to provide higher value to customers [74]. Hence, a firm's growth may become higher as product demand arises due to innovative activities. The findings of this study align with previous studies that show how innovation has a positive impact on a firm's performance $[44,46,75,76]$. Especially, a firm can increase its profits, return on sales, expand market share, and meet customer satisfaction levels by applying innovation throughout the organization. This will result in innovative products and services [77,78]. Innovation helps organizations in achieving sustainable growth. Innovation leads to the development of new management strategies that help solve problems and redesign the production line faster than its competitors.

This study also enriches the literature stream by testing the moderating role of the external environment on the relationship between innovation and SME performance. The hypothesis testing results revealed the positive nexus among innovation and SME performance, but the relationship between innovation and SME performance intensity changes. In a pressurized environment, external factors cause firms to be highly active to perform and compete. In other words, firms that are exposed to a dynamic environment are capable of bringing changes into the organization more quickly by innovation. Therefore, these firms can gain an edge over their competitors. The product and services offering surpasses its competitors. Such firms can access customer information rapidly and meet their criteria efficiently and effectively. These findings are consistent with the views of [79], who stated that the rate of innovation is high in dynamic environments. In this study, a moderating analysis was done to examine the relationship between the two variables when a moderator is present. Thus, the external environment was assumed to change the strength of the relationship between innovation and firm performance [80].

The findings show that the relationship between these variables was enhanced in the turbulent environment [81]. Moreover, the findings also demonstrate that the performance of firms is greater and the level of innovation is higher where there is intense competition [82]. Firms that have a higher capability to innovate when compared to another firm's resources are more effective in responding to environmental changes and developing new capabilities $[46,83]$. Nowadays, the core aims of SMEs are not only to innovate, survive, or be profitable in a dynamic business environment, but also to strive for innovative new markets and remain in the competition. On the one hand, current findings support a previous researcher who argues that innovation increases the risk to one's investments [84]. However, at the same time, our findings support previous research that postulates that when uncertainty and changes in the environment are high, there are more opportunities for the firm to utilize these opportunities by engaging in innovation activities. Ultimately, these activities will enhance the learning capabilities of firms [85].

The current research emphasized the significant impact of innovation and the external environment on an SME's performance. These findings will undoubtedly be useful to academia and practitioners in their future decisions. Previous studies have mostly focused on large firms and developed economies to test these variables. In contrast, our current study focused on SMEs in a developing country and thus fills a gap in the literature. This 
study has implications for policy-makers since it provides an insight into the way that SMEs can support their innovation activities using their resources. SME owners/managers need to ensure that their firms provide clients with products and services of unique benefits, offer innovative ideas and solutions to a client's problems, and encourage employees to look for novel ways of problem-solving. This could assist policy-makers in their issuance of regulations that urge market practices to support the maximization of innovation in SMEs. More importantly, it could improve the relationship between government entities and industrial SMEs as the pillar of economic development of the country. The government bodies should provide financial instruments to support innovation, such as R\&D framework programs and structural funds, to improve the business environment and thus the functionality of the SMEs. Finally, the outcome of this study is expected to be used by the Pakistani government and agencies to develop the best strategies to enhance the textile industry SMEs in Pakistan, in conjunction with initiatives aimed at increasing cooperation with foreign companies to increase their experiences and support their competencies to exploit externally generated knowledge.

\section{Limitation and Recommendation}

Despite the major contributions of our research, it has a few limitations that must be taken into consideration. Firstly, the data were gathered by a self-administered survey technique from a single respondent in an organization that could potentially bias our results. Thus, a goal for future studies would be to focus on collecting data from multiple informants in an organization. Since the coefficient of determination ( $R^{2}$ value) accounted for $40.6 \%$ of the variance in the endogenous variable, namely SME performance, there are some other factors or variables that may contribute to the remaining variance in the endogenous variable. Therefore, future studies would stand to benefit by adding some other independent variables, mediation, or another moderator in the current model. The present study was cross-sectional. For greater knowledge, generalizability, and understanding of the relationships, future studies could focus on longitudinal data and comparative research related to the current variables (innovation, the external environment, and SME performance). Furthermore, similar studies can be conducted in other sectors and developing countries for greater generalizability of the findings. Finally, this study focused on SME performance using a general perspective, i.e., from an economic standpoint. In this regard, future research could focus on other aspects of performance, such as social and environmental concerns.

For practitioners, this model and the outcomes of this study may serve as a useful guide to all stakeholders, including policymakers, relevant administrative departments, and individual organizations and professionals. The results of this study may lead to improved performance and enhanced innovation by mitigating the impact of a disturbance in the external environment. For academia, this research is significant as it may become the basis for the inclusion of other environmental factors (political stability, social and demographic influence, etc.) to further expand the model. Additional environmental influences may lead to more clarity and broad-based generalization of this model.

Author Contributions: All of the authors contributed to conceptualization, formal analysis, investigation, methodology and writing and editing the original draft. All authors have read and agreed to the published version of the manuscript.

Funding: This research received no external funding.

Institutional Review Board Statement: Not applicable.

Informed Consent Statement: Informed consent was obtained from the respondents of the survey.

Data Availability Statement: The data will be made available on request from the corresponding author.

Acknowledgments: We would like to thank Nguyen Tat Thanh University, Ho Chi Minh City, Vietnam for the support of time and facilities for this study.

Conflicts of Interest: The authors declare no conflict of interest. 


\section{References}

1. Jiménez, E.; de la Cuesta-González, M.; Boronat-Navarro, M. How Small and Medium-Sized Enterprises Can Uptake the Sustainable Development Goals through a Cluster Management Organization: A Case Study. Sustainability 2021, 13, 5939. [CrossRef]

2. Ferreira, J.; Coelho, A.; Moutinho, L. Dynamic capabilities, creativity and innovation capability and their impact on competitive advantage and firm performance: The moderating role of entrepreneurial orientation. Technovation 2020, 92, 102061. [CrossRef]

3. Tian, Q.; Zhang, S.; Yu, H.; Cao, G. Exploring the factors influencing business model innovation using grounded theory: The case of a Chinese high-end equipment manufacturer. Sustainability 2019, 11, 1455. [CrossRef]

4. Kuzma, E.; Padilha, L.S.; Sehnem, S.; Julkovski, D.J.; Roman, D.J. The relationship between innovation and sustainability: A meta-analytic study. J. Clean. Prod. 2020, 259, 120745. [CrossRef]

5. Tajeddini, K.; Trueman, M. The potential for innovativeness: A tale of the Swiss watch industry. J. Mark. Manag. 2008, 24, 169-184. [CrossRef]

6. Sumrit, D.; Anuntavoranich, P. An analytic network process modeling to assess technological innovation capabilities: Case study for Thai automotive parts firms. Am. Trans. Eng. Appl. Sci. 2013, 2, 189-212.

7. Ge, B.; Jiang, D.; Gao, Y.; Tsai, S.-B. The influence of legitimacy on a proactive green orientation and green performance: A study based on transitional economy scenarios in china. Sustainability 2016, 8, 1344. [CrossRef]

8. Saji, B.S.; Ellingstad, P. Social innovation model for business performance and innovation. Int. J. Product. Perform. Manag. 2016, 65, 256-274. [CrossRef]

9. Turulja, L.; Bajgoric, N. Innovation, firms' performance and environmental turbulence: Is there a moderator or mediator? Eur. J. Innov. Manag. 2019, 22, 213-232. [CrossRef]

10. Gunday, G.; Ulusoy, G.; Kilic, K.; Alpkan, L. Effects of innovation types on firm performance. Int. J. Prod. Econ. 2011, 133, 662-676. [CrossRef]

11. Rajapathirana, R.P.J.; Hui, Y. Relationship between innovation capability, innovation type, and firm performance. J. Innov. Knowl. 2018, 3, 44-55. [CrossRef]

12. Saleem, H.; Li, Y.; Ali, Z.; Mehreen, A.; Mansoor, M.S. An empirical investigation on how big data analytics influence China SMEs performance: Do product and process innovation matter? Asia Pacific Bus. Rev. 2020, 26, 537-562. [CrossRef]

13. Aboelmaged, M.; Hashem, G. Absorptive capacity and green innovation adoption in SMEs: The mediating effects of sustainable organisational capabilities. J. Clean. Prod. 2019, 220, 853-863. [CrossRef]

14. Yousaf, Z.; Radulescu, M.; Sinisi, C.I.; Serbanescu, L.; Păunescu, L.M. Towards sustainable digital innovation of SMEs from the developing countries in the context of the digital economy and frugal environment. Sustainability 2021, 13, 5715. [CrossRef]

15. Hung, K.-P.; Chou, C. The impact of open innovation on firm performance: The moderating effects of internal R\&D and environmental turbulence. Technovation 2013, 33, 368-380. [CrossRef]

16. Chan, H.K.; Yee, R.W.Y.; Dai, J.; Lim, M.K. The moderating effect of environmental dynamism on green product innovation and performance. Int. J. Prod. Econ. 2016, 181, 384-391. [CrossRef]

17. Ting, H.-F.; Wang, H.-B.; Wang, D.-S. The moderating role of environmental dynamism on the influence of innovation strategy and firm performance. Int. J. Innov. Manag. Technol. 2012, 3, 517. [CrossRef]

18. Arshad, M.Z.; Arshad, D. Internal capabilities and SMEs performance: A case of textile industry in Pakistan. Manag. Sci. Lett. 2019, 9, 621-628. [CrossRef]

19. Arshad, M.Z.; Ahmad, M.J.; Ali, M.; Khan, W.A. The role of government business support services and absorptive capacity on smes performance. Int. J. Adv. Sci. Technol. 2020, 29, 1492-1499.

20. Hong, J.; Zheng, R.; Deng, H.; Zhou, Y. Green supply chain collaborative innovation, absorptive capacity and innovation performance: Evidence from China. J. Clean. Prod. 2019, 241, 118377. [CrossRef]

21. Shin, N.; Park, S.H.; Park, S. Partnership-based supply chain collaboration: Impact on commitment, innovation, and firm performance. Sustainability 2019, 11, 449. [CrossRef]

22. Varis, M.; Littunen, H. Types of innovation, sources of information and performance in entrepreneurial SMEs. Eur. J. Innov. Manag. 2010, 13, 128-154. [CrossRef]

23. Cho, H.; Pucik, V. Relationship between innovativeness, quality, growth, profitability, and market value. Strateg. Manag. J. 2005, 26, 555-575. [CrossRef]

24. de Azevedo Rezende, L.; Bansi, A.C.; Alves, M.F.R.; Galina, S.V.R. Take your time: Examining when green innovation affects financial performance in multinationals. J. Clean. Prod. 2019, 233, 993-1003. [CrossRef]

25. Kafetzopoulos, D.; Psomas, E. The impact of innovation capability on the performance of manufacturing companies. J. Manuf. Technol. Manag. 2015, 26, 104-130. [CrossRef]

26. Purwanto, U.S. The Relationship Between of Manufacturing Flexibility, Innovation Capability, and Operational Performance in Indonesian Manufacturing SMEs. In IOP Conference Series: Materials Science and Engineering; IOP Publishing: Bristol, UK, 2016; Volume 114, p. 12074.

27. Hansen, U.E.; Larsen, T.H.; Bhasin, S.; Burgers, R.; Larsen, H. Innovation capability building in subsidiaries of multinational companies in emerging economies: Insights from the wind turbine industry. J. Clean. Prod. 2020, 244, 118746. [CrossRef]

28. Wadho, W.; Chaudhry, A. Innovation and firm performance in developing countries: The case of Pakistani textile and apparel manufacturers. Res. Policy 2018, 47, 1283-1294. [CrossRef] 
29. Bendickson, J.; Gur, F.A.; Taylor, E.C. Reducing environmental uncertainty: How high performance work systems moderate the resource dependence-firm performance relationship. Can. J. Adm. Sci. Rev. Can. Sci. L'administration 2018, 35, 252-264. [CrossRef]

30. Li, D.; Liu, J. Dynamic capabilities, environmental dynamism, and competitive advantage: Evidence from China. J. Bus. Res. 2014, 67, 2793-2799. [CrossRef]

31. Yayla, A.A.; $\mathrm{Hu}, \mathrm{Q}$. The impact of IT-business strategic alignment on firm performance in a developing country setting: Exploring moderating roles of environmental uncertainty and strategic orientation. Eur. J. Inf. Syst. 2012, 21, 373-387. [CrossRef]

32. McKelvie, A.; Wiklund, J.; Brattström, A. Externally acquired or internally generated? Knowledge development and perceived environmental dynamism in new venture innovation. Entrep. Theory Pract. 2018, 42, 24-46. [CrossRef]

33. Daud, W.N.W.; Remli, N.; Muhammad, H. Market orientation and performance: A study of takaful performance in Malaysia. Asian Soc. Sci. 2013, 9, 240. [CrossRef]

34. Carton, R.B. Measuring Organizational Performance: An Exploratory Study. Ph.D. Thesis, University of Georgia, Athens, GA, USA, 2004.

35. Kennerley, M.; Neely, A. Measuring performance in a changing business environment. Int. J. Oper. Prod. Manag. 2003, 23, 213-229. [CrossRef]

36. Murphy, G.B.; Trailer, J.W.; Hill, R.C. Measuring performance in entrepreneurship research. J. Bus. Res. 1996, 36, 15-23. [CrossRef]

37. Rauch, A.; Wiklund, J.; Lumpkin, G.T.; Frese, M. Entrepreneurial orientation and business performance: An assessment of past research and suggestions for the future. Entrep. Theory Pract. 2009, 33, 761-787. [CrossRef]

38. Hudson, M.; Smart, A.; Bourne, M. Theory and practice in SME performance measurement systems. Int. J. Oper. Prod. Manag. 2001, 21, 1096-1115. [CrossRef]

39. Bititci, U.S.; Nudurupati, S.S.; Turner, T.J.; Creighton, S. Web enabled performance measurement systems: Management implications. Int. J. Oper. Prod. Manag. 2002, 22, 1273-1287. [CrossRef]

40. Hansen, S.-O.; Wakonen, J. Innovation, a winning solution? Int. J. Technol. Manag. 1997, 13, 345-358. [CrossRef]

41. Organisation for Economic Co-operation and Development. OECD Factbook 2005: Economic, Environmental and Social Statistics; OECD: Paris, France, 2005; ISBN 9264084800.

42. Johl, S.K.; Toha, M.A. The Nexus between Proactive Eco-Innovation and Firm Financial Performance: A Circular Economy Perspective. Sustainability 2021, 13, 6253. [CrossRef]

43. Sharma, S.; Prakash, G.; Kumar, A.; Mussada, E.K.; Antony, J.; Luthra, S. Analysing the relationship of adaption of green culture, innovation, green performance for achieving sustainability: Mediating role of employee commitment. J. Clean. Prod. 2021, 303, 127039. [CrossRef]

44. Ramanathan, R.; He, Q.; Black, A.; Ghobadian, A.; Gallear, D. Environmental regulations, innovation and firm performance: A revisit of the Porter hypothesis. J. Clean. Prod. 2017, 155, 79-92. [CrossRef]

45. Choi, S.-K.; Han, S.; Kwak, K.-T. Innovation Capabilities and the Performance of Start-Ups in Korea: The Role of Government Support Policies. Sustainability 2021, 13, 6009. [CrossRef]

46. Martinez-Conesa, I.; Soto-Acosta, P.; Palacios-Manzano, M. Corporate social responsibility and its effect on innovation and firm performance: An empirical research in SMEs. J. Clean. Prod. 2017, 142, 2374-2383. [CrossRef]

47. Otache, I.; Mahmood, R. Corporate entrepreneurship and business performance: The role of external environment and organizational culture: A proposed framework. Mediterr. J. Soc. Sci. 2015, 6, 524. [CrossRef]

48. Sul, H.-K. An Exploratory Model of the Relationships among the External Environment, Entrepreneurial Strategy, Mechanistic-Organic Structure, and Financial Performance of Restaurant Franchisors from the Perspective of Franchisees; Virginia Polytechnic Institute and State University: Blacksburg, VA, USA, 2001.

49. García-Sánchez, E.; García-Morales, V.J.; Martín-Rojas, R. Analysis of the influence of the environment, stakeholder integration capability, absorptive capacity, and technological skills on organizational performance through corporate entrepreneurship. Int. Entrep. Manag. J. 2018, 14, 345-377. [CrossRef]

50. Andersén, J. Strategic resources and firm performance. Manag. Decis. 2011, 49, 87-98. [CrossRef]

51. Dess, G.G.; Beard, D.W. Dimensions of organizational task environments. Adm. Sci. Q. 1984, 29, 52-73. [CrossRef]

52. Jansen, J.J.P.; Van Den Bosch, F.A.J.; Volberda, H.W. Exploratory innovation, exploitative innovation, and performance: Effects of organizational antecedents and environmental moderators. Manag. Sci. 2006, 52, 1661-1674. [CrossRef]

53. Wernerfelt, B. A resource-based view of the firm. Strateg. Manag. J. 1984, 5, 171-180. [CrossRef]

54. Barney, J.; Wright, M.; Ketchen Jr, D.J. The resource based view of the firm. J. Manag. 1991, 26, 342-367.

55. Peter, F.; Adegbuyi, O.; Olokundun, M.; Peter, A.O.; Amaihian, A.B.; Ibidunni, A.S. Government financial support and financial performance of SMEs. Acad. Strateg. Manag. J. 2018, 17, 1-32.

56. Covin, J.G.; Slevin, D.P. Strategic management of small firms in hostile and benign environments. Strateg. Manag. J. 1989, 10, 75-87. [CrossRef]

57. Manu, F.A. Innovation orientation, environment and performance: A comparison of US and European markets. J. Int. Bus. Stud. 1992, 23, 333-359. [CrossRef]

58. Baker, W.E.; Sinkula, J.M. Market orientation, learning orientation and product innovation: Delving into the organization's black box. J. Mark. Manag. 2002, 5, 5-23.

59. Wiklund, J.; Shepherd, D. Entrepreneurial orientation and small business performance: A configurational approach. J. Bus. Ventur. 2005, 20, 71-91. [CrossRef] 
60. Krejcie, R.V.; Morgan, D.W. Determining sample size for research activities. Educ. Psychol. Meas. 1970, 30, 607-610. [CrossRef]

61. Levinson, J.; Peng, K. Valuing Cultural Differences in Behavioral Economics. ICFAI J. Behav. Financ. 2007, 4, 32-47.

62. Potaka, L.; Cochrane, S. Developing bilingual questionnaires: Experiences from New Zealand in the development of the 2001 Mäori language survey. J. Off. Stat. 2004, 20, 289-300.

63. Weerawardena, J. The role of marketing capability in innovation-based competitive strategy. J. Strateg. Mark. 2003, 11, 15-35. [CrossRef]

64. Jaworski, B.J.; Kohli, A.K. Market orientation: Antecedents and consequences. J. Mark. 1993, 57, 53-70. [CrossRef]

65. Valmohammadi, C. The impact of TQM implementation on the organizational performance of Iranian manufacturing SMEs. TQM J. 2011, 23, 496-509. [CrossRef]

66. Hair, J.F., Jr.; Sarstedt, M.; Ringle, C.M.; Gudergan, S.P. Advanced Issues in Partial Least Squares Structural Equation Modeling; SAGE Publications: Thousand Oaks, CA, USA, 2017; ISBN 1483377385.

67. Becker, J.M.; Klein, K.; Wetzels, M. Hierarchical Latent Variable Models in PLS-SEM: Guidelines for Using Reflective-Formative Type Models. Long Range Plan. 2012, 45, 359-394. [CrossRef]

68. Hair, J.F., Jr.; Sarstedt, M.; Hopkins, L.; Kuppelwieser, V.G. Partial least squares structural equation modeling (PLS-SEM). Eur. Bus. Rev. 2014, 46, 1-12.

69. Henseler, J.; Hubona, G.; Ray, P.A. Using PLS path modeling in new technology research: Updated guidelines. Ind. Manag. Data Syst. 2016, 116, 2-20. [CrossRef]

70. Bauer, D.J.; Curran, P.J. Probing interactions in fixed and multilevel regression: Inferential and graphical techniques. Multivar. Behav. Res. 2005, 40, 373-400. [CrossRef] [PubMed]

71. Dawson, J.F. Moderation in Management Research: What, Why, When, and How. J. Bus. Psychol. 2014, 29, 1-19. [CrossRef]

72. Anning-Dorson, T. How much and when to innovate. Eur. J. Innov. Manag. 2017, 20, 599-619. [CrossRef]

73. Porter, M.E.; Millar, V.E. How Information Gives You Competitive Advantage. Harv. Bus. Rev. 1985, 63, 149-160.

74. Avlonitis, G.J.; Salavou, H.E. Entrepreneurial orientation of SMEs, product innovativeness, and performance. J. Bus. Res. 2007, 60, 566-575. [CrossRef]

75. Darroch, J. Knowledge management, innovation and firm performance. J. Knowl. Manag. 2005, 9, 101-115. [CrossRef]

76. Saunila, M.; Ukko, J.; Rantanen, H. Does Innovation Capability Really Matter for the Pro fi tability of SMEs? Knowl. Process Manag. 2014, 21, 134-142. [CrossRef]

77. Ray, S. An integrated operations-marketing model for innovative products and services. Int. J. Prod. Econ. 2005, 95, 327-345. [CrossRef]

78. Yang, F.-H.; Tsai, Y.-S.; Liao, W.-S. Examining the mechanisms linking behavioral integrity and affective commitment: The mediating role of charismatic leadership. Int. J. Organ. Innov. 2014, 6, 153.

79. Prajogo, D.I. The strategic fit between innovation strategies and business environment in delivering business performance. Int. J. Prod. Econ. 2016, 171, 241-249. [CrossRef]

80. Le Nguyen, H.; Larimo, J.; Wang, Y. Control, innovation and international joint venture performance: The moderating role of internal and external environments. Int. Bus. Rev. 2019, 28, 101591. [CrossRef]

81. Du, J.; Peng, S.; Song, W.; Peng, J. Relationship between enterprise technological diversification and technology innovation performance: Moderating role of internal resources and external environment dynamics. Transform. Bus. Econ. 2020, 19, 52-73.

82. Mao, L.; Li, J.; Guo, C. Integrator's Coordination on Technological Innovation Performance in China: The Dual Moderating Role of Environmental Dynamism. Sustainability 2020, 12, 308. [CrossRef]

83. Silvestre, B.S.; Ţîrcă, D.M. Innovations for sustainable development: Moving toward a sustainable future. J. Clean. Prod. 2019, 208, 325-332. [CrossRef]

84. Caggese, A. Entrepreneurial risk, investment, and innovation. J. Financ. Econ. 2012, 106, 287-307. [CrossRef]

85. McGill, M.E.; Slocum, J.W., Jr. Unlearning the organization. Organ. Dyn. 1993, 22, 67-79. [CrossRef] 